\title{
Effect of Caudal Dexmedetomidine on Prevention of Postoperative Agitation after Sevoflurane Anesthesia in Children: A Prospective Randomized Study
}

\author{
ZINB T. RAGAB, M.Sc.; AMR A. MAGDY, M.D.; AHMED A. EL-DABA, M.D. and \\ SOHEIR M. SOLIMAN, M.D.
}

The Department of Anesthesia and Surgical Intensive Care, Faculty of Medicine, Tanta University

\begin{abstract}
Background: Sevoflurane commonly used in pediatric anesthesia for inhalational induction and maintenance, however Emergence Agitation (EA) in children after sevoflurane anesthesia is common, with reported incidence up to $80 \%$. Dexmedetomidine is a selective alpha 2 receptor agonist and has sympatholytic, analgesic and sedative properties with minimal respiratory effects.
\end{abstract}

Aim: The aim of this study is to evaluate the effect of caudal dexmedetomidine on prevention of agitation after sevoflurane anesthesia as a primary outcome measure. Also post-operative analgesia will be studied as secondary outcome measures.

Material and Methods: This study was carried out on 120 children, 1-6 years, ASA I, scheduled for elective lower abdominal surgery. Patients were randomized into 3 equal groups (40 patients in each group): Group I: Dexmedetomidine group (DEX): Received caudal anesthesia with dexmedetomidine $1 \mathrm{ug} / \mathrm{kg}$ and $1 \mathrm{ml} / \mathrm{kg}$ bupivacaine $0.25 \%$, Group II: Received caudal anesthesia with $1 \mathrm{ml} / \mathrm{kg}$ bupivacaine $0.25 \%$. Group III: Received general anesthesia without caudal block. Hemodynamics: (HR \& MAP) and $\mathrm{SpO}_{2}$ before induction and every 10 minutes for 1 st 2 hours andat 15 -min intervals for $1 \mathrm{~h}$. post-operatively, depth of anesthesia, incidence of emergence agitation after extubation and for $10 \mathrm{~min}$ in the PACU by Aono's four-point scale. at 15-min intervals for $1 \mathrm{~h}$. Post-operative pain was assisted by CHIPPS.

Results: Hemodynamics (HR \& MAP) only significant decrease in MAP and HR in DEX group. EA was significantly lower in DEX group, CHIPPS was significantly lower in Group I, BIS value was low in DEX group, fentanyl requirement was lower in Group 1.

Conclusions: The use of dexmedetomidine $(1 \mu \mathrm{g} / \mathrm{kg})$ added to bupivacaine in caudal block in sevoflurane-anaesthetized children significantly decreased the occurrence of EA and prolonged duration of post-operative analgesia.

Correspondence to: Dr. Soheir M. Soliman, The Department of Anesthesia and Surgical Intensive Care, Faculty of Medicine, Tanta University
Key Words: Caudal block - Bupivacaine - Dexmedetomidine - Emergence agitation - Sevoflurane.

\section{Introduction}

EMERGENCE Agitation (EA) from general anesthesia may lead to self extubation or removal of catheters, which can cause serious complications as hypoxia, aspiration pneumonia, bleeding or reoperation [1]. The exact cause of emergence agitation in children is unknown but several risk factors may be encountered such as: Intrinsic characteristics of an anesthetic, rapid emergence from anesthesia, post-operative pain, preschool age and preoperative anxiety [2] .

Sevoflurane commonly used in pediatric anesthesia for inhalational induction and maintenance for its several advantages, however EA in children after sevoflurane anesthesia is common, with reported incidence up to $80 \%$ [3]

Dexmedetomidine is a selective alpha 2 receptor agonist and has sympatholytic, analgesic and sedative properties [4]. Dexmedetomidine has a fewer incidences of side effects and highly selective to receptors which might permit its application in a relatively high doses for sedation and analgesia without causing vascular complications from activation of alphal receptors $[\mathbf{5 , 6}]$. Also, one of the major advantages of dexmedetomidine over other sedatives is its minimal respiratory effects [7].

\section{Material and Methods}

This study was carried out in Tanta University Hospitals in Pediatric Surgery Department on patients of both sexes aged from 1 to 6 years old with ASA physical status I scheduled for elective 
lower abdominal or lower limb surgery for six months from January 2016 to June 2016. Exclusion criteria were: Parents' refusal, upper air way infection 2 weeks ago or less, fever, allergy to bupivacaine or dexmedetomidine, general contraindication to caudal block asbleeding and coagulation disorders, and patient with neurological problems, specially affecting lower limb.

Written informed consent was obtained from the parents of all children. Every parent received an explanation to the purpose of the study. Research results were only used for scientific purposes. Procedures were approved by the Institutional Ethical Committee. The privacy of participants and confidentiality of data were guaranteed. Any unexpected risks appeared during the course of research were clarified to the participants and the Ethical Committee on time.

The study was designed as prospective randomizeddouble blind clinical trial. After sample size calculation the total number of patients was equal to 120 . Patients were randomly classified into three groups: Group I: Consist of 40 patients, received caudal anesthesia with dexmedetomidine and bupivacaine, dexmedetomidine in a dose $1 \mathrm{ug} / \mathrm{kg}$ and bupivacaine $2.5 \mathrm{mg} / \mathrm{ml}, 1 \mathrm{ml} / \mathrm{kg}$ Group II: Consist of 40 patients; received caudal anesthesia with bupivacaine alone $2.5 \mathrm{mg} / \mathrm{ml}, 1 \mathrm{ml} / \mathrm{kg}$. Group III: Consist of 40 patients: Received general anesthesia only without caudal block.

The randomization was performed using sealed enveloped technique indicating the group of the assignment. A blinded nurse, who did not participate in the study or data collection, read the number contained in the envelope and made group assignments. The caudal was performed by me under supervision of my staff, data was collected by another college.

\section{Anesthetic management:}

Pre-operative management: The medical condition of the patients was evaluated, clinical examination was performed and routine laboratory investigations were done including complete blood picture, bleeding time and clotting time. Appropriate pre-operative fasting period: Patients were fed breast milk up to $4 \mathrm{hrs}$ before induction, whereas infant formula and light meal were given up to $6 \mathrm{hrs}$ before induction. Clear fluids (water and nonpulp juice) were given until $2 \mathrm{hrs}$ before induction. No premedication was given.

Intra operative management: On entering operating room, all patients were monitored by stand- ard monitoring as pulse oximetry, non-invasive blood pressure and three leads ECG.

Inhalational induction was done by sevoflurane in oxygen via a face mask as soon as the child lost consciousness a $22 \mathrm{G}$ cannula was inserted. Fentanyl $1 \mathrm{~g} / \mathrm{kg}$ and cis-atracurium, $0.15 \mathrm{mg} / \mathrm{kg}$ were given to three groups, until child became deeply anesthetized, after that orotracheal tube of appropriate size was inserted. The maintenance was done by sevoflurane $2 \%$ guided by multi gas analyzer and maintenance dose of fentanyl and muscle relaxant.

Appropriate glucose-containing solutions were given according to body weight using formula; for maintenance $4 \mathrm{ml} / \mathrm{kg}$ for the first $10 \mathrm{~kg}, 2 \mathrm{ml} / \mathrm{kg}$ for the second $10 \mathrm{~kg}$ and $1 \mathrm{ml} / \mathrm{kg}$ for the rest body weight, $1 \mathrm{ml} / \mathrm{kg}$ for third space and deficit were calculated.

The equipment required for caudal block includes: ( 2 syringes of 22 gauge diameter, povidoneiodine (Betadine) solution 10\% for sterilization, local anesthetic solution bupivacaine $0.5 \%$ and dexmedetomidine).

The patient was in the lateral position complete aseptic technique is used sterilization of skin with betadine sterile drapes for covering area around site of injection then the sacral hiatus was identified by first palpating the coccyx, and then sliding the palpating finger in a cephalad direction (towards the head) until a depression in the skin was felt. The site of sacral hiatus was confirmed by drawing the triangle formed by the hiatus and the posterior superior iliac spines. Once the sacral hiatus is identified the area above is carefully cleaned with antiseptic solution, and a 22 -gauge short beveled cannula or needle is directed at about $45^{\circ}$ to skin and inserted till a "click" is felt as the sacrococcygeal ligament is pierced. The needle is then carefully directed in a cephalad direction at an angle approaching the long axis of the spinal canal.

The needle should be aspirated looking for either CSF or blood. A small amount of local anesthetic should be injected as a test dose (2$4 \mathrm{mls}$ ). It should not produce either a lump in the subcutaneous tissues, or a feeling of resistance to the injection, nor any systemic effects such as arrhythmias, or hypotension. If the test dose does not produce any side effects then the rest of the drug is injected, the needle removed and the patient positioned for surgery.

In Group I: Caudal anesthesia with dexmedetomidine and bupivacaine in Group II: Received caudal anesthesia with bupivacaine alone $2.5 \mathrm{mg} / \mathrm{ml}$, 
$1 \mathrm{ml} / \mathrm{kg}$ and in Group III: Received general anesthesia only without caudal block.

At the end of the procedure general anesthesia was discontinued after regaining of spontaneous breathing reversal of muscle relaxant with prostagmine and atropine was given, the tracheal tube was removed and. Patients were transferred to the recovery room for continuous monitoring of vital signs and assessment of pain.

Measurements: Demographic data including (age, sex, weight, type of operation and duration of surgery). Duration of surgery is defined as time from being ready to start skin incision till end of operation. Hemodynamics (HR and arterial blood pressure and $\mathrm{SpO}_{2}$ ) before induction and every 10 minutes for 1 st 2 hours then every 15 minutes till end of surgery. Depth of anesthesia $=$ BIS between 40-60 adjusted by fentanyl requirement. Incidence of emergence agitation after extubation and for 10 min in the PACU by Aono'sfour-pointscale [8] (Calm: Point 1 , not calm, but could be easily calmed: Point 2, moderately agitated or restless: Point 3, combative, excited, disoriented: Point 4). In the PACU HR, arterial blood pressure and $\mathrm{SpO}_{2}$ was recorded at 15 -min intervals for $1 \mathrm{~h}$. Postoperative pain was assisted by Children's Andinfant's Post-operative Pain Scale (CHIPPS) (Table 1) [9], and recorded at post-operative 15, 30, 60, $120 \mathrm{~min}$ and then every $1 \mathrm{hr}$. (Until CHIPPS score above 10). If the CHIPPS score is 10 or below, there is no need for additional analgesia. If the score is above 10 , it is accepted that there is a need for additional analgesia and $15 \mathrm{mg} / \mathrm{kg}$ rectal paracetamol is administered.

The sample size calculation is performed using EpI-Info 2002 software statistical package designed by World Health Organization (WHO) and by Centers for Disease Control and Prevention (CDC). The sample size is calculated as $\mathrm{N}>36$ based on the following considerations: $95 \%$ confidence limit, $90 \%$ power of the study, 1:2 ratio of non-exposed to exposed and expected primary outcome to be $65 \%$ of required among non-exposed compared to $90 \%$ of required among the best exposed group.

Statistical presentation and analysis was conductedby SPSS V.24. Results were expressed as means \pm Standard Deviation (SD). Student paired t.test: For statistical analysis within the same group. ANOVA test: Used for comparison of parametric data (age, weight, duration of surgery, HR, MAP and $\mathrm{SpO}_{2}$ ) between the two studied groups. Modified chi-square test for small numbers: For comparison between two groups as regards qualitative data (sex). $p$-value $<0.05$ was considered significant.

Table (1): (CHEEPS).

\begin{tabular}{|c|c|c|}
\hline Item & Behavioral & Score \\
\hline \multirow[t]{4}{*}{ Cry } & No cry & 1 \\
\hline & Moaning & 2 \\
\hline & Crying & 2 \\
\hline & Scream & 3 \\
\hline \multirow[t]{3}{*}{ Facial } & Composed & 1 \\
\hline & Grimace & 2 \\
\hline & Smiling & 0 \\
\hline \multirow[t]{5}{*}{ Child verbal } & None & 1 \\
\hline & Other complaints & 1 \\
\hline & Pain complaints & 2 \\
\hline & Both complaints & 2 \\
\hline & Positive & 0 \\
\hline \multirow[t]{6}{*}{ Torso } & Neutral & 1 \\
\hline & Shifting & 2 \\
\hline & Tense & 2 \\
\hline & Shivering & 2 \\
\hline & Upright & 2 \\
\hline & Restrained & 2 \\
\hline \multirow[t]{5}{*}{ Touch } & Not touching & 1 \\
\hline & Reach & 2 \\
\hline & Touch & 2 \\
\hline & Grab & 2 \\
\hline & Restrained & 2 \\
\hline \multirow[t]{5}{*}{ Legs } & Neutral & 1 \\
\hline & Squirming/kicking & 2 \\
\hline & Drawn up/tensed & 2 \\
\hline & Standing & 2 \\
\hline & Restrained & 2 \\
\hline
\end{tabular}

\section{Results}

As regards to demographic data (age, sex and weight), duration of surgery and type of surgery, there was no significant difference among three groups (Table 2). Regarding to the hemodynamics, the three groups were hemodynamically stable. However, DEX group had stable hemodynamic effect with no occurrence of bradycardia and the intraoperative heart rate was significantly lower than the two other groups Figs. $(1,2)$. As regard $\mathrm{SpO}_{2}$, there is no significant difference in the three groups pre-operative, intraoperative and postoperative. As regard BIS value (depth of anesthesia), there was significant decrease in Group I compared to Group II and III and between Group II and III Fig. (3). The incidence and severity of agitation was significantly lower in DEX group compared to the two other groups Fig. (4). There was significant difference among three groups at post-operatively but CHIPPS score was significantly lower in DEX group than two other group Fig. (5). As regard time for 1 st analgesic requirement, 
there is significant decrease in Group III than Group I and Group II compared to Group I Fig. (6). As regard fentanyl requirement intraoperative there was significant increase in fentanyl requirement in Group III compared to Group I and II Fig. (7).

Table (2): Demographic data in the three study groups.

\begin{tabular}{lllll}
\hline & $\begin{array}{c}\text { Group I } \\
\mathrm{N}=40\end{array}$ & $\begin{array}{c}\text { Group II } \\
\mathrm{N}=40\end{array}$ & $\begin{array}{c}\text { Group III } \\
\mathrm{N}=40\end{array}$ & $\begin{array}{c}p \text { - } \\
\text { value }\end{array}$ \\
\hline Age & $1-6$ & $1-6$ & $1-6$ & 0,5272 \\
$\begin{array}{l}\text { Sex: } \\
\quad \text { Male }\end{array}$ & 37 & 35 & 33 & 0.4 \\
$\quad$ Female & 3 & 5 & 7 & \\
Weight & 15.425 & 15.225 & 14.025 & 0.209 \\
Duration of Surgery & 41.95 & 42 & 42.95 & 0.06 \\
$\begin{array}{l}\text { Type of surgery: } \\
\quad \text { Open orchipexy }\end{array}$ & 25 & 22 & 23 & 0.819 \\
$\quad \begin{array}{l}\text { Inguial hernia } \\
\text { DDH }\end{array}$ & 10 & 14 & 14 & \\
\hline
\end{tabular}
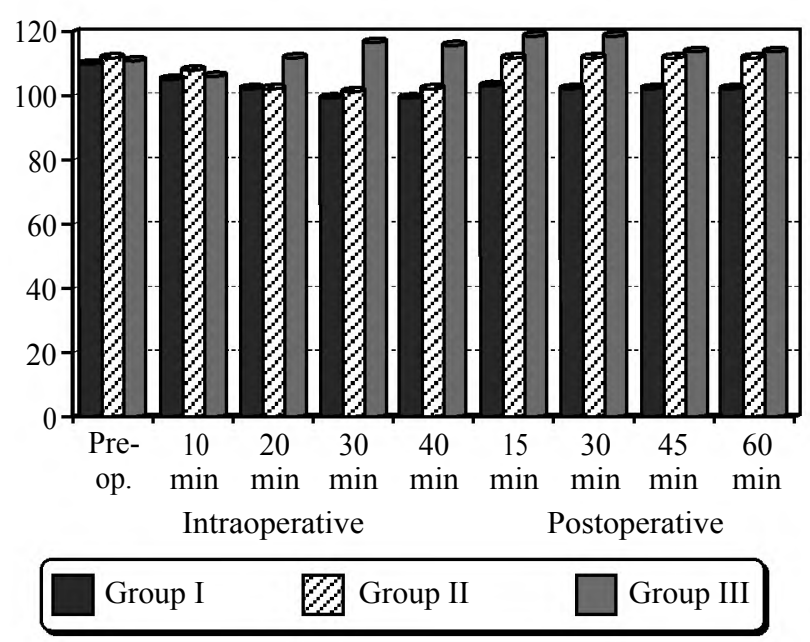

Fig. (1): Comparison of heart rate between three studied groups.

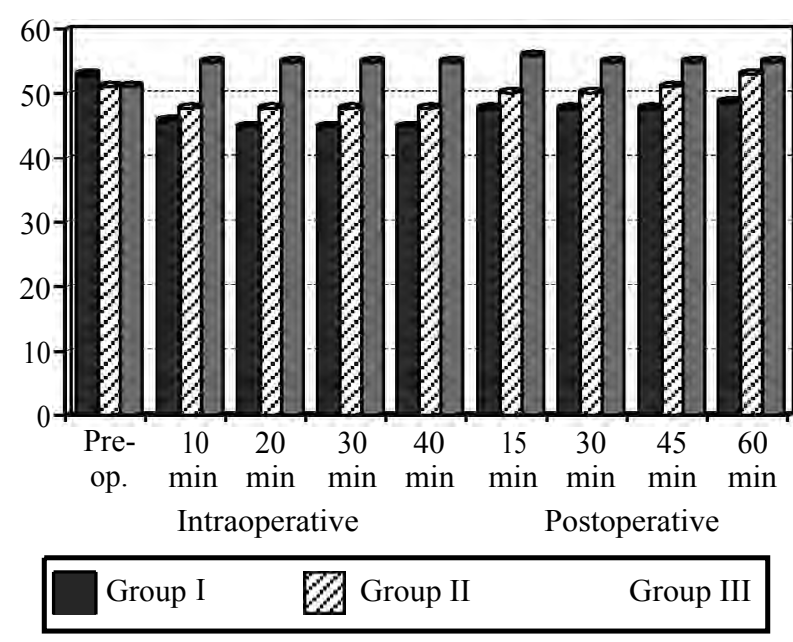

Fig. (2): Comparison of MAP in the three studied group.

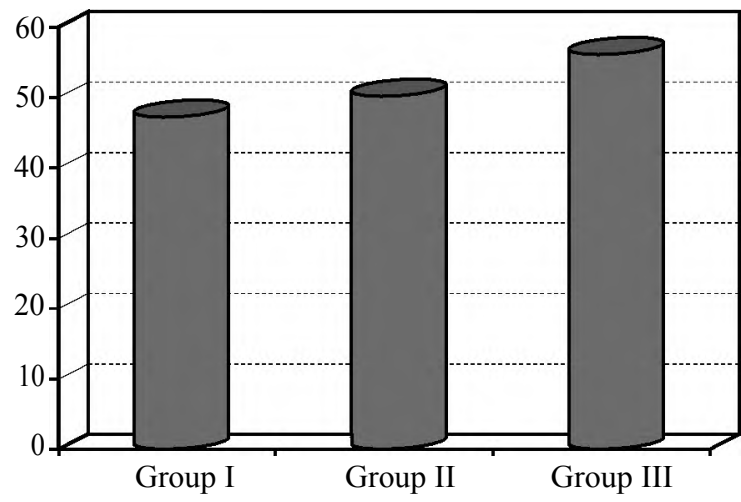

Fig. (3): Comparison of BIS in the three studied groups.

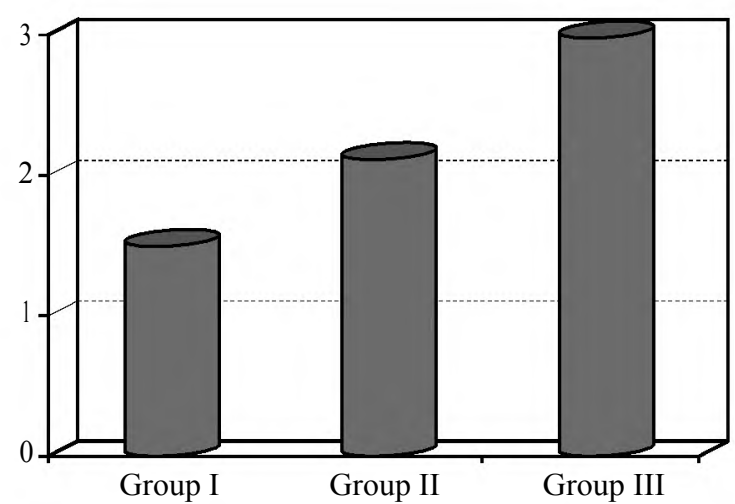

Fig. (4): Incidence of emergence agitation in the three studied groups.

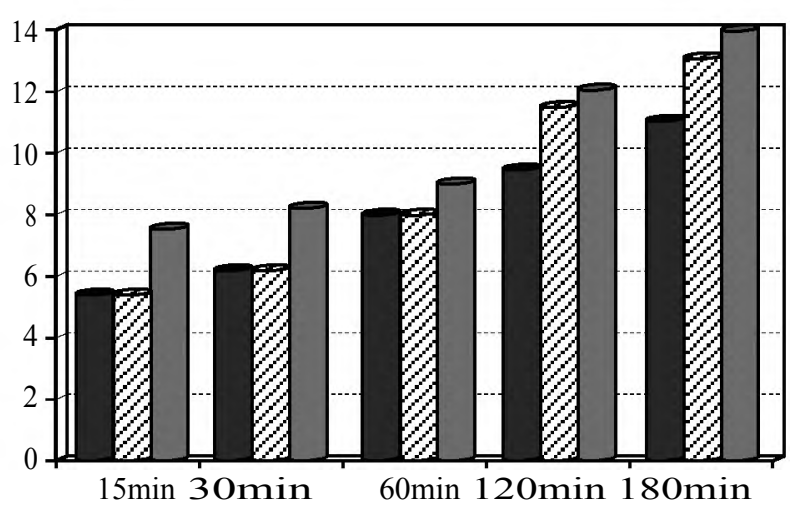

Fig. (5): Comparison of CHIPPS in the three studied groups.

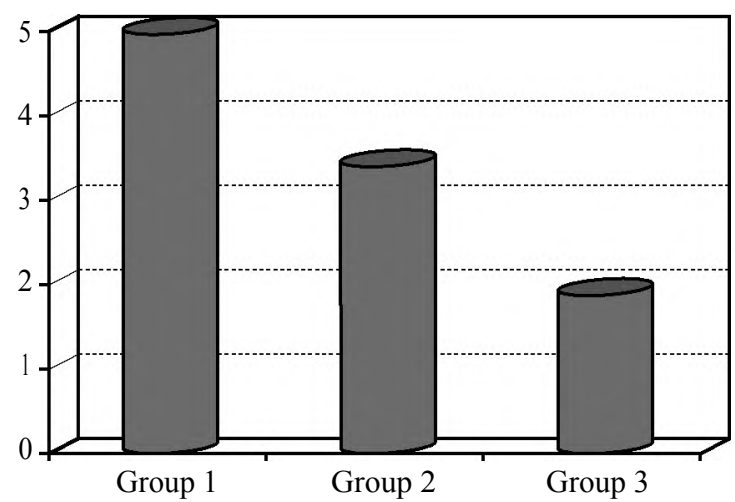

Fig. (6): 1 st time for analgesia requirementin the three studied groups. 


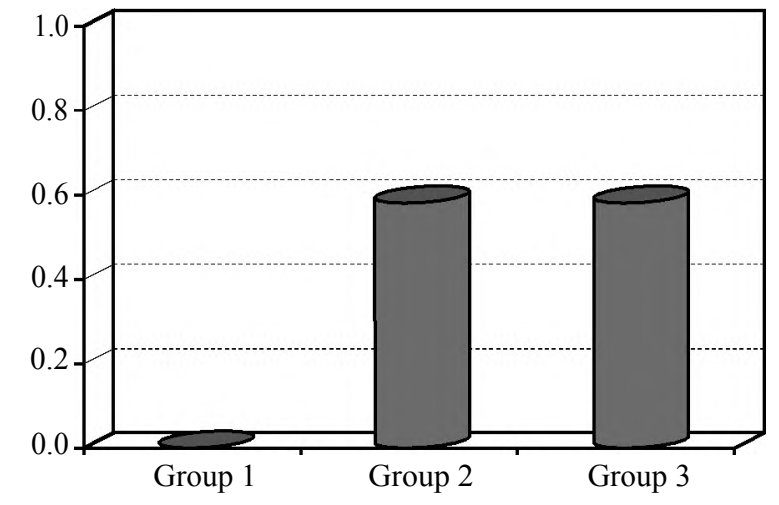

Fig. (7): Comparison of fentanyl requirement in the three studied groups.

\section{Discussion}

As regards to demographic data (age, sex \& weight) there was no significant difference among three groups.

Regarding to the hemodynamics: The three groups were hemodynamically stable. However, dexmedetomidine group had stable hemodynamic effect with no occurrence of bradycardia, the intraoperative heart rate in DEX group was significantly lower than the two groups. In agreement with our study, Saadawyet al., [10], this study reported decrease in heart rate and mean arterial pressure in dexmedetomidine group within 25-35 min of caudal administration.

In our study, the incidence and severity of agitation was significantly lower in group 1 compared to group 2 and group 3 . In agreement with our study, Shukry et al., [11] who study if dexmedetomidine prevent emergence delirium in children after sevoflurane anesthesia. Also in agreement with our study, Stato et al., [12] who studied the effect of single dose dexmedetomidine effect on emergence agitation and recovery profiles after sevoflurane anesthesia. Also in agreement with our study Ibacache et al., [13] who studied single dose dexmedetomidine reduce agitation after sevoflurane anesthesia.

Also in agreement with our study, Saadawy et al., [10], who compared the effect of caudal injection of $1 \mathrm{ml} / \mathrm{kg}$ of bupivacaine $2.5 \mathrm{mg} / \mathrm{ml}$ and the same dose of bupivacaine mixed with DEX $1 \mathrm{mic} / \mathrm{kg}$ in patient undergoing unilateral inguinal hernia repair ororchipexy. Also in agreement with our study, Bock et al., [14] andBoker et al., [15] showed that the incidence of agitation following sevoflurane anesthesia was significantly lower with dexmedetomidine children who received caudal dexmedetomidinehad better quality of sleep. Similar finding was observed by Anand et al., who observed that patients receiving caudal dexmedetomidine $2 \mathrm{tg} / \mathrm{kg}$ with $0.25 \%$ ropivacaine $1 \mathrm{ml} / \mathrm{kg}$ forpediatric lower abdominal surgeries had significant post-operative pain relief [21]

As regard pain assessment there was significant decrease in CHIPPS score in the DEX group. El Shammaa et al., [22] who studied the effects of adding caudal DEXor morphine to bupivacaine in children undergoing infra umbilical surgeries and concluded that there was significant prolongation in the duration of post-operative analgesia. In agreement with our study, El-Hennawy et al., [16] who administered dexmedetomidine and clonidine, both in a dose of $2 \mu \mathrm{g} / \mathrm{kg}$ as adjuvant with $0.25 \%$ bupivacaine caudally. They found that the duration of analgesia was significantly higher in the group receiving bupivacaine-dexmedetomidine mixture and found also that the CHIPPSwas significantly lower in that group than the bupivacaine alone administered group. Also in agreement with our study, Neogi et al., [17]: Who administered clonidine $1 \mathrm{lg} / \mathrm{kg}$ and dexmedetomidine $1 \mathrm{mic} 1 / \mathrm{kg}$ as adjuncts to ropivacaine $0.25 \%$ for caudal analgesia in pediatric patients and concluded that addition of both clonidine and dexmedetomidine with ropivacaine administered caudally significantly increases the duration of analgesia. Also in agreement with our results, Ali and Abdelatif [18]: Studied prevention of sevoflurane related emergence agitation in children undergoing adenotonsillectomy acomparison of dexmedetomidine and propofol.

As regard fentanyl requirement intraoperative there was significant increase in fentanyl requirement in Group 3 compared to Group 2 and Group 1. In agreement with our results XIANG et al., [19] : who studied 'Caudal dexmedetomidine combined with bupivacaine inhibit the response to hernia sac traction in children undergoing inguinal hernia repair'.

As regard depth of anesthesia and BIS value there was significant decrease in the BIS value in Group 1 compared to Group 2 and Group 3 also between Group 2 and Group 3. In agreement with our results Kasuya et al., [20] who studied. The correlation between bispectral index and observational sedation scale in volunteers sedated with dexmedetomidine and propofol.

\section{Conclusions:}

The use of dexmedetomidine $(1 \mu \mathrm{g} / \mathrm{kg})$ added to bupivacaine in caudal block in sevofluraneanaesthetized children significantly decreased the 
occurrence of EA and prolonged duration of postoperative analgesia.

\section{Conflicts of interest:}

No conflicts of interest declared.

\section{Authors' Contributions:}

All authors had equal role in design, work, statistical analysis and manuscript writing.

\section{References}

1- GULER G., AKIN Z., TOSUN E., et al.: Single-dose dexmedetomidine attenuates airway and circulatory reflexes during extubation. Acta Anaesthesiol. Scand.; 49: 1088-91, 2005.

2- VLAJKOVIC G.P. and SINDJELIC R.P.: Emergence delirium in children: Many questions, few answers. Anesth. Analg.; 104: 84-91, 2007.

3- GOODEN R., TENNANTB I., JAMESA B., et al.: The incidence of emergence delirium and risk factors following sevoflurane use in pediatric patients for day case surgery, Kingston, Jamaica. Rev. Bras. Anestesiol.; 64: 413-8, 2014.

4- GERLACH A.T. and DASTA J.F.: Dexmedetomidine: An updated review. Ann. Pharmacother.; 41: 245-52, 2007.

5- YOSHITOMI T., KOHJITANI A., MAEDA S., et al.: Dexmedetomidine enhance the local anesthetic action of lidocaine via an alpha-2A adrenoceptor. Anesth. Analg.; 107: 96-101, 2008

6- KOROGLU A., DEMIRBILEK S., TEKSAN H., et al.: Sedative, haemodynamic and respiratory effects of dexmedetomidine in children undergoing magnetic resonance imaging examination: Preliminary results. Br. J. Anaesth.; 94: 821-4, 2005.

7- AGGARWAL A., KAUR H., BATRA Y.K., et al.: Anatomic consideration of caudal epidural space. Clin. Anat.; 22: 730-7, 2009.

8- SIKICH N. and LERMAN J.: Development and psychometric evaluation of the pediatric anesthesia emergence delirium scale. Anesthesiol.; 100: 1138-45, 2004.

9- CRAVERO J.P., BEACH M., THYR B., et al.: The effect of small dose fentanyl on the emergence characteristics of pediatric patients after sevoflurane anesthesia without surgery. Anesth. Analg.; 97: 364-7, 2003.

10- SAADAWY I., BOKER A., ELSHAHAWY M.A., et al.: Effect of dexmedetomidine on the characteristics of bupivacaine in a caudal block in pediatrics. Acta. Anaesthesiol. Scand.; 53: 251-6, 2009.
11- SHUKRY M., CLYDE M.C., KALARICKAL P.L., et al.: Does dexmedetomidine prevent emergence delirium in children after sevoflurane-based general anesthesia? Paediatr. Anaesth.; 15: 1098-104, 2005.

12- SATO M., SHIRAKAMI G., TAZUKE-NISHIMURA M. et al.: Effect of single-dose dexmedetomidine on emergence agitation and recovery profiles after sevoflurane anesthesia in pediatric ambulatory surgery. J. Anesth.; 24: 675-82, 2010.

13- IBACACHE M.E., MUÑOZ H.R., BRANDES V., et al. Single dose dexmedetomidine reduces agitation after sevoflurane anesthesia in children. Anesth. Analg.; 98 (60): 63, 2004.

14- BOCK M., KUNZ P., SCHRECKENBERGER R., et al.: Comparison of caudal and intravenous clonidine in the prevention of agitation after sevoflurane in children. Br. J. Anaesth.; 88: 790-6, 2002.

15- BOKER A., SAADAWY I., ELSHAHAWY M.A., et al.: Effect of dexmedetomidine on the characteristics of bupivacaine in a caudal block in pediatrics. Acta. Anaesthesiol. Scand.; 53: 251-6, 2009.

16- EL-HENNAWY A.M., ABD-ELWAHAB A.M., ABDELMAKSOUD A.M., et al.: Addition of clonidine or dexmedetomidine to bupivacaine prolongs caudal. Analgesia in children. Br. J. Anaesth.; 103: 268-74, 2009.

17- NEOGI M., BHATTACHARJEE D.P., DAWN S., et al.: A comparative study between clonidine and dexmedetomidine used as adjuncts to ropivacaine for caudal analgesia in paediatric patients. J. Anaesthesiol. Clin. Pharmacol.; 26: 149-53, 2010.

18- ALI M.A. and ABDELLATIF A.A.: Prevention of sevoflurane related emergence agitation in children under goingadenotonsillectomy: A comparison of dexmedetomidine and propofol. Saudi J. Anaesth.; 3 (7): 296-300, 2013.

19- IANG Q., HUANG D.Y., ZHAO Y.L., et al.: Caudal dexmedetomidine combined with bupivacaine inhibit the response to hernial sac traction in children undergoing inguinal hernia repair'. British Journal of Anaesthesia; 110: 420-4, 2013.

20- KASUYA Y., GOVINDA R., RAUCH S., et al.: The correlation between bispectral index and observational sedation scale in volunteers sedated with dexmedetomidine and propofol. Anesth. Analg.; 109: 1811-5, 2009.

21- ANAND V.G., KANNAN M., THAVAMANI A. and Bridgit M.J.: Effects of dexmedetomidine added to caudal ropivacaine in paediatric lower abdominal surgeries. Indian J. Anaesth.; 55: 340-6, 2011.

22- EL-SHAMAA H.A. and IBRAHIM M.: A comparative study of the effect of caudal dexmedetomidine versus morphine added to bupivacaine in pediatric infra-umbilical surgery. Saudi J. Anesth.; 8: 155-60, 2014. 


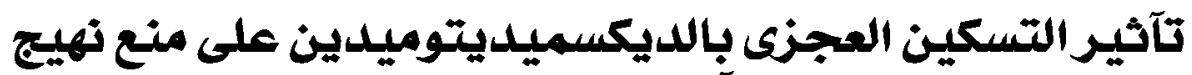

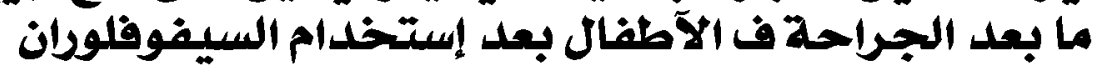 دراسلة عشوائية مستثقبلية فئية}

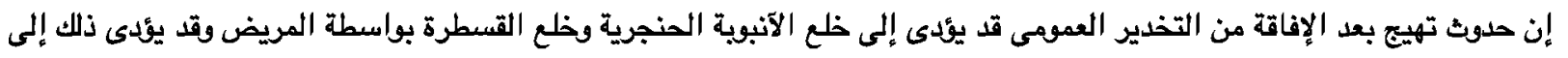

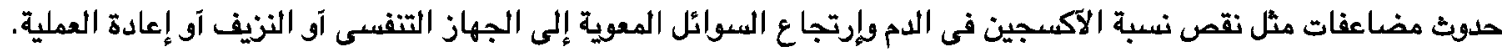
إن السبب الحقيقى لحدث التهيج فى الآطفال غير معرف ولكن هناك عوامل تساعد على حدوث التهيج مثل خواص المخدر وآلم ما بعد العملية وفى آعمار معينة في الآطفال من سن سنة إلى الى 7 سنوات.

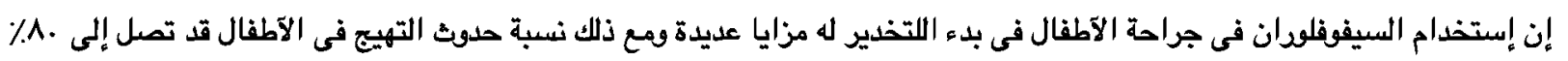
مع إستخدام السيفوفلوان.

الهدف هو تقييم تآثير إستخدام الديكسميديتوميدين فى التسكين العجزى على منع تهيج ما بعد الإقاقة من التخدير العمومي بعد إستخدام

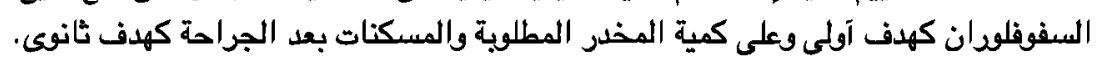

تم تنفيذ هذه الدراسة العثوائية في مستشفى جامعة طنطا خلال 17 . بعد موافقة لجنة الآخلاق تم آخذ: موافقة من آولياء آمود المرضى. تم إجراء البحث على • r ا طفلا من سن سنة إلى 7 سنوات من الدرجة الآولى طبقا للجمعية الآمريكية لآطباء التخدير الذين تم خضوعهم لجراحة آسفل البطن بإستخدام مخدر السيفوفلوران.

تم تخدير المرضى بإستخدام (السيفوفلوارن) والفنتانيل آميكرجرام لكل كيلوجرام في التسكين العجزى وتم تقسيم المرضى إلى: المجموعة الآولى: وتم إعطاء بييوفيكين امل لكل كيلوجرام وديكسمديتوميدين آميكوجرام لكل كيلوجرام فى التسكين العجزى. الهجموعة الثانية: لقد تم إعطائهم بيبوفيكين امل لكل كيلوجرام فى التسكين العجزى. المجموعة الثالثة: لقد تم إعطائهم مخدر عام فقط بدون تسكين عجزى.

• وقد تبين آنه إضافة عقار الديكسوميدين إلى البيوبيفيكين ف التسكين العجزى يقل من حدوث التهيج ما بعد الجراحة كما يقلل من إحتياج جرعة المسكنات بعد الجراحة. 